\title{
第58回日本木材学会大会に参加して
}

2008年 3 月 17 日からの 3 日間にわたり第58回日 本木材学会大会が茨城県つくば市で開催された。 本大会では，前大会の発表件数561件に近い553件 （口頭297件，ポスター256件）の発表が行われ，多 数の研究者が活発な議論を交わしていた。また， 発表，公開シンポジウム，懇親会など，大会関連 行事は全てつくば国際会議場（エポカルつくば） 内で開催され，発表会場間の移動がスムーズに行 えるなど，限られた時間を有効に活用できる快適 な大会だった。

保存分野での発表件数は，口頭発表が18件，ポ スター発表が16件となっていた。以下に各発表内 容を筆者の独断により分類し，その概要を報告す る。（）内に示したのは講演番号である。なお, 筆者の不勉強により，発表内容を十分に扮伝えで きない部分があれば，何卒ご容赦いただきたい。

\section{劣化調査 ・劣化評価に関する研究}

劣化と強度の関係に関する研究, 屋外構造物の 劣化調査に関する研究などとして，以下のような 発表がみられた。

東大農の前田ら（PN014）は, 腐朽により構造物 が破壊に至るまでの挙動をシミュレートする手法 の構築を目的として, 室内での強制腐朽試験を行 い, 試験体強度の経時的変化や試験体強度と密度 分布との関係などについて報告した。

森林総研の加藤ら（PN013）は, 野外に設置され ていた杭の目視被害度と曲げ強さとの間には相関 が認められなかったが，同試験体について縦振動 法により測定したヤング係数と曲げ強さとの間に は相関が認められたと報告した。
遠山昌之*

北林産試の森ら（PN015）は, 野外試験地に設置 した円柱材及び杭材の縦圧縮強さの経年変化を調 べ，試験体の形状により残存強度が異なることを 示した。また, 円柱材の同一円周上 4 点の平均ピ ロディン打ち込み深さと縦圧縮強さに高い相関が あることを示し，ピロディンによって残存強度を 推定できる可能性を示唆した。

京大生存研の森ら（N18-1330）は, シロアリ食 害材の残存耐力の推定を目的として, 強度性能と 非破壊測定值との関係を求める試験を実施した。 材の密度と曲げ強度及びヤング係数との間には相 関があることを示した。一方，超音波伝搬速度と 曲げ強度，ヤング係数及び全面圧縮に扔ける降伏 強度との関係についても示したが，食害の大きな 材では超音波測定が難しいことなど, 超音波伝搬 速度の測定による強度性能の推定の難しさを示す 報告だったと思われた。

超音波による劣化状況の測定については，森林 総研の桃原ら（N18-1345）が, 蟻害材の超音波伝

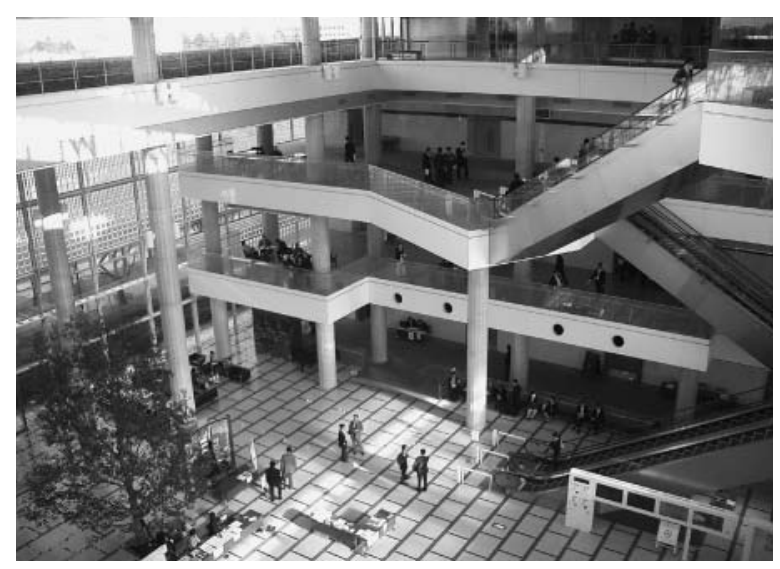

第58回日本木材学会大会会場 
搬速度について, 対面法と同一面法により測定し， 断面欠損率が10\%を超えるような蟻害材を対面法 で測定した場合に，蟻害の有無を有効に検出でき ることを示した。しかし, 超音波速度の低下が検 出できない断面欠損率 $5 \%$ 付近で横圧縮強度が急 激に低下寸る場合があり, 初期の蟻害を感度良く 検出する方法の開発が必要であると述べた。

群馬林試の町田ら（PN016）は,木製遮音壁の劣 化状況調査から，上端に笠木が設置されていない タイプや植栽木の枝下にある遮音壁では, 劣化ユ ニットの出現率が高いことを示し，木製遮音壁の 耐久性を向上させるためのポイントを提起した。

長野林総七の柴田ら（N18-1400）は, 設置後20 年を経過したカラマツ製遮音壁部材を調査し, 材 面は灰褐色となり,割れやねじれが生じていたが， 腐朽は局所的に軽微なものが認められる程度であ り, 密度, 動的ヤング係数及びピロディン打ち込 み深さの測定でも著しい劣化は認められなかった と報告した。

森林総研の末吉ら（N18-1415）は, 長野林総セ の柴田らが調査した設置後20年を経過したカラマ ツ製遮音壁の音響透過損失を測定し, 部材間の隙 間がなければ，遮音壁設置基準を満足する遮音性 能が得られることを示した。

\section{素材・木質系材料の耐久性に関する研究}

素材及び木質系材料の耐久性に関する研究とし ては，以下のような発表がみられた。

熊本林研指の遠山ら（PN011）は, 野外試験及び 室内試験の結果から，スギ精英樹の耐朽性及び耐 蟻性についてクローン間で違いがあることを示し た。また，へキサン及びメタノールによる抽出成 分 (総量) が多いクローンほど，耐朽性及び耐蟻 性が高い傾向があると述べた。

森林総研の大村ら (PN012) は, 高耐久性樹種と される15樹種の耐蟻性について調べ，ヤマトシロ アリを用いた室内試験では，耐候操作により質量 減少が顕著となる樹種があることや, 室内試験で は高い耐蟻性を示した樹種が野外では食害を受け たことなどを明らかにした。

森林総研の木口ら（PN005）は,木粉含量の異な る木粉・プラスチック複合材（WPC）の耐水性を 明らかにするため, 室温下水中浸漬, 高湿度下,
煮沸, ファンガスセラー, 室内強制腐朽の各試験 を行い, 木粉含量 $40 \%$ 以上では吸水性が認められ, ファンガスセラーに 1 年間埋設した試験体では 2 〜 3\%の質量減少が見られると報告した。

\section{保存処理}

新規の保存処理薬剤や薬剤の処理方法に関連す る研究, 薬剂を使用せずに木材等の耐久性向上を 図る研究，保存処理を行った廃材の処理に関する 研究などとしては, 以下のような報告がみられた。 富山林技七の栗崎ら（N18-1100）は, 廃食用油 から調製した銅石畭を溶解し, スギ辺材に注入処 理及び塗布処理を行った結果, 室内試験及び野外 試験において, JIS に基づく防蟻性能が確認でき たと報告した。また，この銅石畧の防蟻効果は主 として摂食忌避作用と考えられると述べた。

京大生存研の吉村ら（N18-1115）は, 酸化リチ ウムと二酸化ケイ素を主剂とする新規製剂がJIS に基づく防腐・防蟻性能（注入処理用）を満たし， 防腐性能には主剤であるリチウムシリケートが, 防蟻・殺蟻効力には界面活性剂であるパーフルオ ロアルキル化合物が重要な役割を果たしているこ とを示した。

高知森技七の松岡ら (PN008) は, パラフィン高 温液相処理を行ったスギ丸棒材の野外暴露試験を 行い,縦方向に地面に打ち込んだ材の被害度が 2.5 に達したのは, 無処理材で46ケ月, パラフィン処 理材で70ケ月だったと報告。また, 地面から離し 水平に設置した無処理材では割れの発生が顕著 で，内部腐朽が進行していたと述べた。

北林産試の宮内ら（PN007）は, 銅・アルキルア ンモニウム化合物系木材保存剤の有効成分として 使用されている塩化ベンザルコニウムの同族体間 における溶脱率の違いについて検討し, 蒸留水及 び人工海水を用いた試験では C14より $\mathrm{C} 12$ の溶脱 率が高いが，フェノール性化合物が含まれる溶液 中では C12より C14の溶脱率が高いことなどを明 らかにした。

東京農工大の Md. Nazrul Islam ら（PN006）は, インサイジング密度, 浸透時間及び乾燥の有無の 違いによる保存処理剂の浸透量及び保持力につい て明らかにした。

岩手林技セの谷内（PN009）は, 薬剤を使用せず 
にアカマツ丸太の青変被害を抑制する方法を見出 すため, 貯木管理方法に着目し, 積算温度と青变 被害の拡大との関係について調査した。その結果， 積算温度が $500^{\circ} \mathrm{C}$ ・日以下の場合に青変被害を大 幅に抑制できることを明らかにし，岩手県内にお いては，伐採から乾燥までの工程を $4 \sim 6$ 月では 5 週間以内， $7 \sim 9$ 月では 3 週間以内に行えば青 変被害を抑制できると述べた。なお，この発表は， 保存分野のポスター賞を受賞された。誠におめで とうございます。

鹿大農の松田ら（N18-1045）は, 煮沸処理した モウソウチクから製造した粉末を投入した中で飼 育されたイエシロアリの死虫率が無処理の場合と 比べ顕著に高くなったことを示し，アセトン抽出 後この抗蟻性が低下したことから，アセトンによ り抽出または変質する抗蟻性物質が煮沸により生 成されたと推察した。

Istanbul University の S. Nami Kartal ら（N181530）は，CCA 処理された廃材から銅，クロム， 七素を効率的かつ経済的に除去する吸着剤を見出 すため, 炭や抽出が終わった茶葉など, 天然由来 の12種類の物質の吸着性能を明らかにし, 吸着剤 の量や抽出時間が増すほど, 除去率が増えること などを示した。

\section{耐候性}

光劣化や LVL 等の耐候性に関する研究として, 以下のような報告がみられた。

広島総研の山本ら（PNO04）は, 熱処理した6 樹 種の心材及び 1 樹種の辺材についてガラス透過太 陽光による変色を調べ, 非加熱処理木材の場合と は異なり, 各試験体とも $\mathrm{L}^{*}$ 值が増加し, 明色化に 起因する光退色が起きたと述べた。

産総研の松井ら（N18-1445）は, スギ辺材を用 いた強化 LVL の耐候性及び強度变化について検 討し, 今回の促進劣化試験の範囲内では強度の低 下はみられなかったと報告。より長時間の促進劣 化試験の実施や製造条件の違いによる影響の検討 などが必要と述べた。

Korea Forest Research Institute $の$ Dong Won Son ら（N18-1430）は, CuAzにより保存処理を行った 単板を用いた LVB について, 17ケ月間の暴露試験 を行っても接着性能が低下しないことなどを報告
した。

\section{耐火}

耐火性能に関する研究としては, 以下の報告が みられた。

北林産試の河原崎ら（N18-1500）は, 集成材の 燃焼の進行は樹種で異なり, 樹種によっては燃え しろを少なくできる可能性があることを示唆した。 森林総研の上川ら（N18-1515）は, 耐火性能を 有する集成材の開発を目指し，レーザーインサイ ジングによる難燃薬剤の注入方法や難燃薬剂処理 したラミナの配置等を検討し, 耐火構造認定に必 要な燃え止まり性能を有する断面仕様を明らかに した。

\section{シロアリ}

シロアリに関する研究としては, 以下のような 報告がみられた。

秋田県大木高研の黄ら（PN010）は, ヤマトシロ アリの基亜種と四国亜種の違いについて，兵蟻の 頭部の違いによって見分けることが可能であるこ とや，摂食量及び蟻道形成率に違いがあることを 報告した。

近大農の南部ら（N18-0915）は，ヤマトシロア リにおいて職蟻から兵蟻への変態を抑制するタン パク質とされる hexamerin の遺伝子の塩基配列を 解析し, 完全長 cDNA が得られと報告した。

近大農の板倉ら（N18-1015）は, ブナシメジ廃 菌床の水抽出画分にヤマトシロアリの産卵誘引物 質（あるいは幼形成熟分化促進物質）が含まれ， 成分分析の結果, ジヒドロキシル化されたカフェ 酸などとオリゴ糖とのエステルに類する構造を持 つ化合物であると推定されると報告した。

京大農の上谷ら（N18-1030）は, ゼオライト粉 末とセメントを混合したゼオライト造粒材料は, ゼオライト原石破砕物とほぼ同等の吸放湿性を持 ち, シロアリ貫通阻止性能もあることを明らかに し, 高湿化防止による床下環境改善機能とシロア リに対する物理的バリア機能を兼ね備えた材料で あることを示した。

\section{生物化学的研究}

木材腐朽菌の酵素や遺伝子に関する研究, 腐朽 
菌の検出に関する研究などとして，以下のような 発表がみられた。

近大院農の城戸ら（PN003）は,木材細胞壁の腐 朽に関与していると考えられる水酸化ラジカル生 成遺伝子を解析し, 遺伝子 glp 1 の完全長 cDNA が得られたことを報告した。

近大農の浜田ら（N18-0945）は, 褐色腐朽菌キ チリメンタケの菌体害分泌物質を含む水溶液から 分子量約15000の糖タンパクを分離したこと報告 し, 褐色腐朽菌による腐朽機構について考察した。

京大生存研の渡邊ら（N18-0930）は，シュウ酸 耐性を指標とした出芽酵母を用いた機能スクリー ニングにより, 褐色腐朽菌オオウズラタケから， 細胞外へのシュウ酸排出に関与すると考えられる 膜タンパク質の cDNAを単離したことなどを報 告した。

高知工科大の堀沢ら (PN002) は, 木材腐朽菌株 に関するデータベース構築を目指し, 京大生存研 DOL に保存されている木材腐朽菌株について情 報を整理したところ, DOL 保存株の中に, 同定の 誤り及び株の置き換わりが疑われるものがあった ことなどを報告した。

京大院農の策瀬ら（N18-1000）は, 木材の腐朽 を初期段階で検出する方法を検討するため, 腐朽 菌から発生するガスを検出した結果, 水素と一酸 化炭素が放出されており, 特に一酸化炭素の発生 が顕著であったことを示した。

京大生存研の豊海ら（PN001）は,ベ夕基礎工法 と土壤あらわし工法による 2 種類の床下環境を設 定し, 床下空間浮遊菌, 土台付着菌, 地表菌の开 ンプリングを行い，いずれのカテゴリーにおいて
も採取された菌は, 土畩あらわし工法のほうが多 かったこと, また, 採取された菌には木材腐朽能 カがあったと報告した。

\section{その他}

生物劣化研究会の講演会が「木材保存を取り巻 く現状と展望」と題して大会最終日に開催された。 まず，(財)日本住宅・木材技術センターの杉山 慎吾氏から，2007年11月15日に承認されたISO 21887 (Durability of wood and wood-based products）ユースクラスの概要と本規格制定までの詳 細な経緯, さらに今後の課題等について説明があ った。

また, 独森林総合研究所の松永浩史氏からは, 近年，米国で ACQ に代わる地位を占めつつある MCQ の防腐性能や分光学的な観点から見た固着 性などに関する研究結果について説明があった。

さらに,ブリティッシュ・コロンビア大学の

Philip. D. Evans 教授からは, 北米における木材保 存を取り巻く現状について説明があった。Evans 教授は, 北米における木材保存関連企業やその主 力商品に関する基本的な話題から, $\mathrm{CCA}$ の使用規 制やポスト CCA 薬剂の特性, 建築物内のカビの 発生に対して訴訟が起こされているため建築物の 抗菌処理が進んでいる現状など, 木材保存分野に おける最近の変化とその背景に関する話題まで説 明され，分かりやすく，北米の現状を知ることが できる貴重な講演であった。

なお, 以上の講演内容の詳細については, 本誌 上で別途紹介される予定とのことである。

(2008. 3 .31受付) 